\title{
Perubahan parameter biologik jaringan kanker payudara mencit akibat pemberian isoflavon tempe
}

\author{
The biological parameter changes of mice breast cancer as the impact of injecting \\ tempeh isoflavone
}

Siti Harnina Bintari ${ }^{1}$, Siti Fatimah Moeis ${ }^{2}$, Sarjadi $^{2}$

\begin{abstract}
Background: Cancer is severe diseases caused by the changing of deoxyribonucleic acid (DNA) structure. Women who consume soy products have a lower risk for breast cancer, but it cannot be explained the kind of biomolecular aspects of soy product which gives this role.

Objective: The aim of this research was to analyze the biological parameter changing of AgNORs, p53, Cas -3 and $\mathrm{Bcl}-2$ in mouse (Mus musculus) $\mathrm{C} 3 \mathrm{H}$ strain with breast cancer, as the impact of injecting isoflavone of tempeh.

Method: The laboratory experimental research was done by posttest only randomized controlled group design. Subject of study were 18 mice (Mus musculus) $\mathrm{C} 3 \mathrm{H}$ strain that were divided into 3 groups, each of which consists of 6 mice. The first group, the control $(K)$, was not injected by isoflavone, while the second group $(P 1)$ and the third group (P2) were injected by $1.000 \mathrm{mg}$ and $10.000 \mathrm{mg}$ of tempeh isoflavone/kg diet/day, respectively. All groups were given the transplanted breast cancer cells. AgNORs parameters were selected to determine the level of proliferation and p53 parameters, Cas-3 and Bcl-2 to determine the appearance of apoptosis. Data were analyzed by using Manova and discriminant test for each parameter of cell proliferation.

Results: Concentration of isoflavones supplementation with 1,000 and 10,000 mg / $\mathrm{kgdiet} /$ day gave effect to the reduction in AgNORs blots, expression of p53 and Cas-3 and increased expression of Bcl-2 in group P1 and P2 compared with control group, as indicated by high statistical values $(p=0.000)$ between both groups or within the group. Results of discriminant test showed that Bcl-2 and AgNORs had dominant role in increased apoptosis and inhibition of cancer cell proliferation in experimental animal.

Conclusion: Tempeh isoflavones can be used as a biological parameter change agent that marks the proliferation and apoptosis of mice (Mus musculus) $\mathrm{C} 3 \mathrm{H}$ strain towards the normal cell cycle progression.
\end{abstract}

KEY WORDS: AgNORs, p53, Cas-3, Bcl-2, breast cancer, tempeh isoflavones

\section{ABSTRAK}

Latar belakang: Kanker merupakan penyakit keganasan yang disebabkan oleh perubahan struktur DNA, yang pada stadium dini belum bisa diketahui tanpa melalui pemeriksaan secara molekuler. Pertumbuhan sel kanker dapat diamati pada setiap tahapan stadium, tetapi memerlukan pendekatan atau metode yang berbeda. Studi epidemiologi menyatakan bahwa wanita yang mengkonsumsi produk olahan kedelai berisiko lebih rendah terkena kanker payudara. Namun, belum dapat dijelaskan perubahan aspek biomolekuler kanker payudara pada penderita yang mengkonsumsi olahan kedelai.

Tujuan: Penelitian bertujuan untuk mempelajari perubahan parameter biologik AgNORs, p53, Cas-3, dan Bcl-2 pada kanker payudara mencit (Mus musculus) galur C3H karena pemberian isoflavon tempe.

Metode: Penelitian eksperimen laboratorik dilakukan dengan rancangan posttest only randomized controlled group design. Subjek penelitian adalah 18 mencit (Mus musculus) galur $\mathrm{C} 3 \mathrm{H}$ yang dibagi dalam 3 kelompok. Kelompok 1 yaitu kelompok kontrol $(K)$ tidak diberi isoflavon, sedangkan kelompok $2\left(P_{1}\right)$ dan $3\left(P_{2}\right)$ masingmasing mendapat 1.000 dan $10.000 \mathrm{mg}$ isoflavon tempe/kg diit/hari. Parameter AgNORs dipilih untuk menentukan tingkat proliferasi sedangkan parameter p53, Cas-3, dan Bcl-2 untuk penentuan munculnya apoptosis. Semua kelompok memperoleh transplantasi sel kanker payudara. Data dianalisis dengan Manova dan diskriminan tiap parameter proliferasi sel.

Hasil: Suplementasi isoflavon dengan konsentrasi 1.000 dan $10.000 \mathrm{mg} / \mathrm{kg}$ diit/hari memberikan efek pada penurunan bercak AgNORs, ekspresi p53, dan Cas-3 serta peningkatan ekspresi Bcl-2 pada kelompok $P_{1}$ dan $P_{2}$ dibandingkan kontrol secara statistik sangat bermakna $(p=0,000)$ baik antar kelompok maupun dalam kelompok. Hasil uji diskriminan menunjukkan bahwa Bcl-2 dan AgNORs memegang peranan dominan pada peningkatan apoptosis dan penghambatan proliferasi sel kanker hewan coba.

Simpulan: Isoflavon tempe dapat digunakan sebagai agensia pengubah parameter biologik penanda proliferasi dan apoptosis mencit Mus musculus galur C3H menuju pada progresivitas siklus sel normal.

KATA KUNCI: AgNORs, p53, Cas-3, Bcl-2, kanker payudara, isoflavon tempe

Universitas Negeri Semarang, Jl. Raya Sekaran, Gunung Pati, Semarang, Telp. (024) 8508033, e-mail: ninabintari@yahoo.com

2. Bagian Gizi Klinik, Program Pendidikan Dokter Spesialis, Fakultas Kedokteran Universitas Diponegoro, Jl. Dokter Sutomo No 18, Semarang 50231, Telp. (024) 7460013, e-mail: sitifatimahmuis@gmail.com 


\section{PENDAHULUAN}

Kanker payudara disebabkan oleh faktor endogen yaitu genetik dan hormonal. Faktor endogen disebabkan oleh adanya mutasi gen dan gen pembawa sifat kanker payudara yang diturunkan $(1,2)$. Faktor endogen hormonal disebabkan oleh kenaikan hormon estrogen baik relatif maupun absolut dalam tubuh. Estrogen merupakan senyawa yang dapat menstimulasi proliferasi sel dan peningkatan ukuran sel (2).

Perubahan pada tingkat molekuler berkaitan dengan perubahan pada tingkat seluler dan dapat digunakan untuk menilai tingkat progresivitas sel kanker pada tubuh hospes. Perubahan tingkat molekuler pada sel kanker payudara dapat dilihat dari regulasi siklus sel ke arah siklus sel normal, yaitu p53 dan gen p21/cyclin dependent kinase inhibitor (CDKI) yang berperan penting dalam mengatur terhambatnya sel rusak masuk ke fase $S$ dan tetap berada di fase $G_{1}$. Perubahan yang terlihat pada bercak AgNORs, ekspresi gen p53, Cas-3, dan $\mathrm{Bcl}-2$ dapat digunakan sebagai indikator perubahan tingkat proliferasi dan apoptosis sel kanker payudara (3-7).

Gen p53 mengkode protein p53 yaitu pada kondisi kerusakan deoxyribonucleic acid (DNA) terjadi peningkatan ekspresi protein p53 dan akan menginduksi apoptosis atau tertahan pada fase $\mathrm{G}_{1}(8)$. Pada saat terjadi abnormalitas DNA, maka p53 ini akan terikat pada DNA sehingga terjadi stabilitas. Selanjutnya, karena kondisi stabil tersebut, protein p53 akan terakumulasi sehingga memberi sinyal pada gen p21/CDKI yang berfungsi menghambat ekspresi gen untuk protein cyclin dependent kinase-2 (Cdk-2) $(9,10)$. Protein p21 ini akan menghambat proses fosforilasi yang dilakukan oleh Cdk-2 terhadap siklin A dan E, serta oleh Cdk-4 terhadap siklin D1 dan D2 $(11,12)$. Genistein dapat meningkatkan regulasi p21 CDKI, menurunkan regulasi cyclin $\mathrm{B}$, dan menginduksi apoptosis atau apoptogenik pada sel kanker prostat (13).

Pada tingkat molekuler dan seluler, dengan bertambahnya pemberian isoflavon yang bersifat antikanker dan apoptogenik dapat menyebabkan perubahan ukuran jaringan kanker secara signifikan (14). Mekanisme yang mendasari perlambatan proliferasi tidak terlepas dari sifat opoptogenik dari isoflavon yaitu apoptosis dikendalikan oleh berbagai protein antara lain kelompok Bcl-2. Penderita kanker payudara dengan Bcl-2 proapoptosis positif mempunyai prognosis yang lebih baik dibandingkan penderita kanker payudara dengan tipe Bcl-2 antiapoptosis. Fenomena apoptosis atau sel mati yang diperantarai oleh induksi Bcl-2 dapat diketahui dan ditentukan oleh ekspresi Cas-3 (Gambar 1) $(7,15)$.

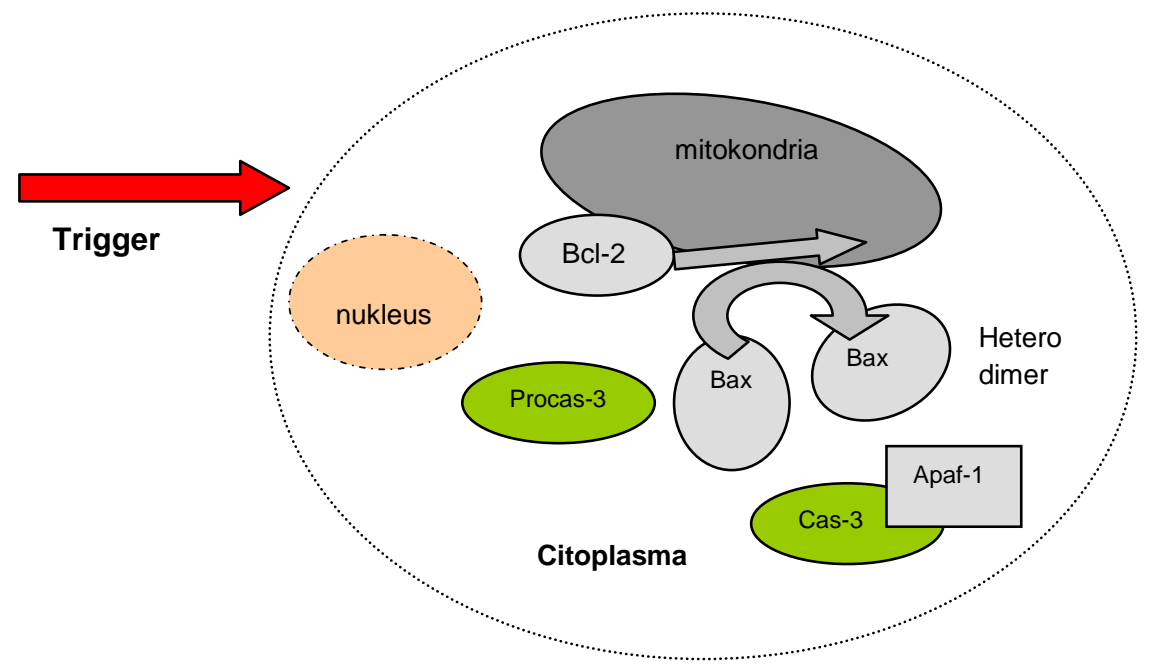

Gambar 1. Pembentukan heterodimer antara Bcl-2 dengan Bax yang menginisiasi apoptosis (modifikasi) (15). 
Isoflavon dilaporkan dapat menghambat pertumbuhan sel kanker melalui penghambatan pembentukan enzim tirosin protein kinase; menghambat enzim DNA topoisomerase pada proses replikasi DNA; dan isoflavon mempunyai efek antiangiogenik melalui penghambataan pembentukan enzim kolagenase oleh sel kanker dan pembentukan senyawa inbibitor cox-2 (16-19). Tempe mengandung isoflavon kurang lebih $50 \mathrm{mg} / 100$ gram tempe (20) dan merupakan bahan makanan yang banyak dikonsumsi masyarakat. Komponen isoflavon pada tempe antara lain genistein, yaitu merupakan senyawa aglikon yang pada sel tubuh dapat bersifat agonis atau antagonis. Isoflavon mempunyai sifat dapat menempati reseptor estrogen hospes sehingga dapat mengurangi terjadinya ikatan antara estrogen dengan reseptor estrogen yang pada akhirnya dapat mencegah timbulnya kanker payudara (21).

Studi epidemiologi menunjukkan bahwa perempuan yang mengkonsumsi kedelai atau bentuk olahannya, seperti tahu, tauco, kecap, miso, dan tempe berisiko rendah terhadap kanker payudara $(17,22,23)$. Semua produk tersebut mengandung antioksidan, yaitu isoflavon yang mempunyai peran pada tingkat seluler dan karsinogenesis $(5,19,24,25)$. Tempe mempunyai keunggulan yaitu mengandung senyawa bioaktif isoflavon terutama genistein yang kadarnya lebih tinggi daripada daidzein dan glisitein, serta mengandung senyawa faktor II (6,7,4' tri-hidroksi isoflavon) yang mempunyai aktivitas pengendalian pertumbuhan, antioksidan, inhibitor enzim, dan pertahanan terhadap penyakit $(26,27)$.

Berdasarkan latar belakang tersebut, bahwa konsumsi isoflavon dapat menurunkan risiko kanker payudara maka rumusan masalah penelitian ini adalah bagaimana perubahan biologik parameter AgNORs, p53, Cas-3, dan Bcl-2 pada jaringan kanker payudara mencit (Mus musculus) galur $\mathrm{C} 3 \mathrm{H}$ yang diakibatkan pemberian isoflavon tempe. Penelitian sebelumnya telah dilakukan untuk mengetahui perubahan parameter biologik pada marker kanker AgNORs, p53, Bcl-2, dan Cas-3 dalam hubungannya dengan penurunan jumlah bercak AgNORs dan gen p53 serta peningkatan gen Bcl-2 dan Cas-3 pada hewan coba mencit (Mus musculus) strain $\mathrm{C} 3 \mathrm{H}$ yang ditransplantasi sel kanker payudara. Manfaat penelitian ini adalah untuk menjelaskan bukti terhadap studi epidemiologis yang sudah dilaporkan dan dapat digunakan sebagai dasar untuk penelitian lebih lanjut pada manusia.

\section{BAHAN DAN METODE}

Penelitian dilaksanakan di Laboratorium Histologi Fakultas Kedokteran, Universitas Diponegoro dan Laboratorium Biologi Fakultas Matematika dan IImu Pengetahuan Alam, Universitas Negeri Semarang, dengan rancangan posttest only randomized controlled group design. Hasil penelitian ini merupakan kompilasi dari hasil observasi pada industri kecil menengah tempe, penelitian pendahuluan, dan penelitian utama yang dilakukan dari tahun 2005 sampai dengan 2009. Bahan penelitian berupa tempe yang diambil pada sekali produksi atau satu batch; hewan coba mencit (Mus musculus) galur $\mathrm{C} 3 \mathrm{H}$ berjenis kelamin betina; bubur atau suspensi sel kanker payudara yang berasal dari mencit donor; pakan mencit standar yang diperoleh dari Laboratorium Patologi Eksperimen Fakultas Kedokteran Umum, Universitas Indonesia; dan beberapa reagen kimia. Sampel yang digunakan sebanyak 18 ekor mencit (Mus musculus) strain C3H betina (28).

Variabel bebas adalah pemberian isoflavon tempe dengan konsentrasi 0 pada kelompok kontrol $(\mathrm{K}), 1.000 \mathrm{mg} / \mathrm{kg}$ diit/hari pada kelompok perlakuan $1\left(\mathrm{P}_{1}\right)$, dan 10.000 $\mathrm{mg} / \mathrm{kg}$ diit/hari pada kelompok perlakuan $2\left(\mathrm{P}_{2}\right)$ yang diberikan secara oral. Penentuan konsentrasi tersebut berdasarkan hasil penelitian pendahuluan (18). Variabel tergantung adalah jumlah bercak AgNORs, sel yang mengekspresikan gen p53, Cas-3, dan Bcl-2. Jumlah bercak AgNORs diukur dengan metode pengecatan perak nitrat yang dihitung 
bercak per 100 sel. Sel yang mengekspresikan p53 diketahui dengan pengecatan imunoperoksidase AbMop53/DO7. Sel yang mengekspresikan Bcl-2 diketahui dengan pengecatan imunoperoksidase AbMoBcl-2/100/D5 sedangkan sel yang mengekspresikan Cas-3 diketahui dengan pengecatan imuniperoksidase AbMoCas-3/30S1. Variabel perancu yang dikendalikan meliputi sifat genetik mencit, umur mencit, makanan dan minuman, jenis kelamin, serta berat awal mencit.

Transplantasi sel kanker dari mencit donor kepada hewan coba dilakukan dengan cara injeksi bubur sel kanker dengan pembawa larutan garam fisiologis sebanyak $0,2 \mathrm{~mL}$ secara subkutan di bagian dada. Jumlah diit mencit rata-rata 3-5 gram/hari dengan lama waktu pemberian isoflavon adalah 1,5 bulan dengan jumlah (volume) maksimal suspensi isolat isoflavon yang dapat disonde ke dalam tubuh mencit secara oral maksimal $3 \mathrm{~mL}$. Isolat isoflavon tempe diberikan secara oral dengan metode sonde (gavage) sebanyak $2 \mathrm{~mL}$ setiap 2 hari. Isoflavon diberikan mulai dari awal penelitian (mencit berumur 2,5 bulan) sampai selesai penelitian.

Pengolahan dan analisis data meliputi uji normalitas dan uji homogenitas. Sementara itu, untuk menguji berkurangnya ekspresi bercak AgNORs, p53, Bcl-2, dan meningkatnya ekspresi Cas-3 pada seluruh kelompok digunakan uji Manova sedangkan uji diskriminan untuk mengetahui perubahan jumlah sel pada kelompok dan untuk menentukan kontribusi terbesar dari parameter penelitian.

\section{HASIL}

Hasil penelitian menunjukkan penurunan yang bermakna antara kelompok $\mathrm{K}, \mathrm{P}_{1}$ dan $\mathrm{P}_{2}$ pada ketiga parameter yaitu AgNORs, p53, dan Cas-3. Namun, rerata jumlah sel yang mengekspresikan Bcl-2 meningkat yaitu dari $\mathrm{K}, \mathrm{P}_{1}$, dan $\mathrm{P}_{2}$ berturut-turut adalah 17,6; 38,7; dan $65,0 \mathrm{sel} / 100 \mathrm{sel}(\mathrm{p}=0,000)$ (Tabel 1). Selanjutnya, dilakukan uji LSD yang menunjukkan adanya perbedaan bermakna antara kelompok kontrol dengan kedua kelompok perlakuan pada semua parameter yang diuji.

Tabel 1. Rerata jumlah bercak AgNORs, p53, Cas-3, dan Bcl-2 pada sel kanker hewan coba

\begin{tabular}{cccccccc}
\hline \multicolumn{2}{c}{ Kelompok } & $\mathbf{n}$ & Rerata & SD & $\mathbf{F}$ & $\mathbf{p}$ & Uji LSD \\
\hline AgNORs & $\mathrm{K}$ & 6 & 532,7 & 41,21 & 351,831 & 0,000 & 0,000 \\
& $\mathrm{P}_{1}$ & 6 & 210,7 & 27,82 & & & 0,000 \\
p53 & $\mathrm{P}_{2}$ & 6 & 112,0 & 1,83 & & & 0,000 \\
& $\mathrm{~K}$ & 6 & 40,1 & 7,75 & 95,259 & 0,000 & 0,000 \\
& $\mathrm{P}_{1}$ & 6 & 13,4 & 1,79 & & & 0,000 \\
Cas-3 & $\mathrm{P}_{2}$ & 6 & 4,5 & 1,09 & & & 0,000 \\
& $\mathrm{~K}$ & 6 & 29,5 & 4,62 & 52,464 & 0,000 & 0,000 \\
& $\mathrm{P}_{1}$ & 6 & 12,6 & 5,70 & & & 0,000 \\
Bcl-2 & $\mathrm{P}_{2}$ & 6 & 4,7 & 0,93 & & & 0,000 \\
& $\mathrm{~K}$ & 6 & 17,6 & 1,50 & 316,278 & 0,000 & 0,000 \\
& $\mathrm{P}_{1}$ & 6 & 38,7 & 5,14 & & & 0,000 \\
& $\mathrm{P}_{2}$ & 6 & 65,0 & 1,81 & & & 0,000 \\
\hline \multicolumn{7}{l}{ Keterangan: $\mathrm{K}=$ kontrol; $\mathrm{P}_{1}=$ perlakuan 1; $\mathrm{P}_{2}=$ perlakuan 2; SD = standar deviasi }
\end{tabular}

Penelitian dilakukan dengan disain awal homogen, meliputi sifat genetik, jenis kelamin, umur, berat badan, makanan dan minuman serta tempat dan lingkungan pemeliharaan. Oleh karena itu, untuk dapat mengetahui variabel yang memberi kontribusi terbesar dari 4 (empat) parameter yang berperan yaitu bercak AgNORs, p53, Cas-3, dan Bcl-2, perlu dilakukan uji perubahan tiap variabel pada setiap kelompok perlakuan $\left(P_{1}\right.$ dan $\mathrm{P}_{2}$ ) terhadap kontrol dengan analisis diskriminan. Pada Tabel 2, hasil analisis diskriminan respon penghambatan sel kanker payudara pada hewan coba menunjukkan AgNORs mempunyai nilai perubahan penghambatan jumlah sel relatif yang rendah bila dibandingkan 
perubahan yang ditunjukkan oleh ketiga variabel yang lain yaitu p53, Cas-3, dan Bcl-2. Hal ini berarti isoflavon memiliki peran yang lebih rendah terhadap proses proliferasi sel kanker payudara dibandingkan proses apoptosis yang ditandai dengan parameter p53, Cas-3, dan Bcl-2.

Pada semua kelompok menunjukkan bahwa menurunnya jumlah bercak AgNORs menggambarkan adanya penurunan aktivitas proliferasi sel, diikuti penurunan ekspresi p53. Sementara itu, peran isoflavon pada aktivitas apoptosis lebih signifikan dibandingkan proses proliferasi sel kanker payudara. Hal ini ditunjukkan pada rerata perubahan kelompok $\mathrm{P}_{1}$ dan $\mathrm{P}_{2}$ yaitu menurunnya ekspresi Cas-3 sedangkan ekspresi sel $\mathrm{Bcl}-2$ meningkat pada setiap besar kontribusi Tahap-1, Tahap-2, dan Tahap-3 (Tabel 2). Hal ini merupakan indikasi sistem kontrol gen p53 untuk perintah apoptosis sel kanker.

Tabel 2. Hasil analisis diskriminan respon penghambatan sel kanker payudara mencit hewan coba

\begin{tabular}{|c|c|c|c|c|c|c|c|c|}
\hline \multirow{3}{*}{ Nilai } & \multicolumn{7}{|c|}{ Rerata perubahan pada kelompok } & \\
\hline & \multicolumn{4}{|c|}{$\mathbf{P}_{1}$} & \multicolumn{4}{|c|}{$\mathbf{P}_{2}$} \\
\hline & $\Delta$ AgNORs & $\Delta$ p53 & $\Delta$ Cas-3 & $\Delta \mathrm{Bcl}-2$ & $\Delta$ AgNORs & $\Delta$ p53 & $\Delta$ Cas-3 & $\Delta \mathrm{Bcl}-2$ \\
\hline $\begin{array}{l}\text { Besar kontribusi } \\
(\text { Tahap-1) }\end{array}$ & $-322,0$ & $-26,6$ & $-16,8$ & 21,1 & $-420,7$ & $-35,5$ & $-24,7$ & 47,3 \\
\hline $\begin{array}{l}\text { Besar kontribusi } \\
\text { (Tahap-2) }\end{array}$ & ---- & $-26,6$ & $-16,8$ & 21,1 & ---- & $-35,5$ & $-24,7$ & 47,3 \\
\hline $\begin{array}{l}\text { Besar kontribusi } \\
\text { (Tahap-3) }\end{array}$ & ---- & ---- & 22,2 & 61,0 & ---- & ---- & 45,8 & 210,5 \\
\hline
\end{tabular}

Gambar 2 menunjukkan besar peran gen pada aktivitas antiproliferasi dan apoptosis oleh karena pemberian isoflavon tempe, yaitu secara umum ekspresi AgNORs dan ekspresi ketiga gen ( $\mathrm{p} 53$, Cas-3, dan Bcl-2) memberikan aktivitas antiproliferasi dan apoptogenik. Adapun gambaran sel yang mengekspresikan bercak AgNORs, p53, Bcl-2, dan Cas-3 (anak panah) pada sel kanker payudara mencit (Mus musculus) galur $\mathrm{C} 3 \mathrm{H}$ terlihat pada Gambar 3 $(a-d)$.

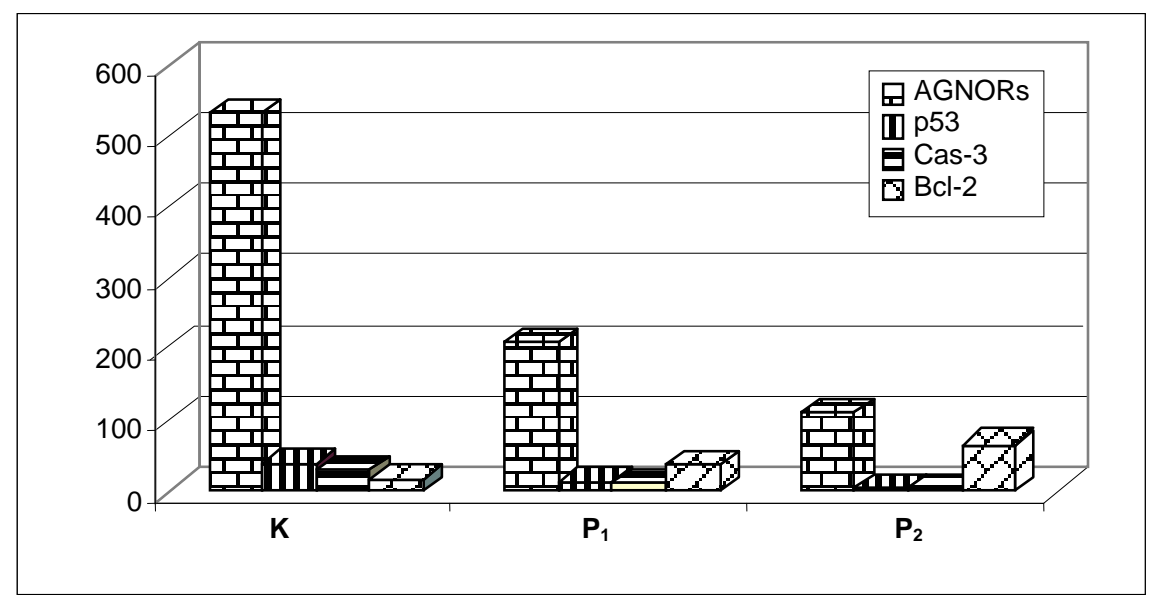

Gambar 2. Besarnya peran gen-gen yang menghambat proliferasi sel kanker hewan coba 


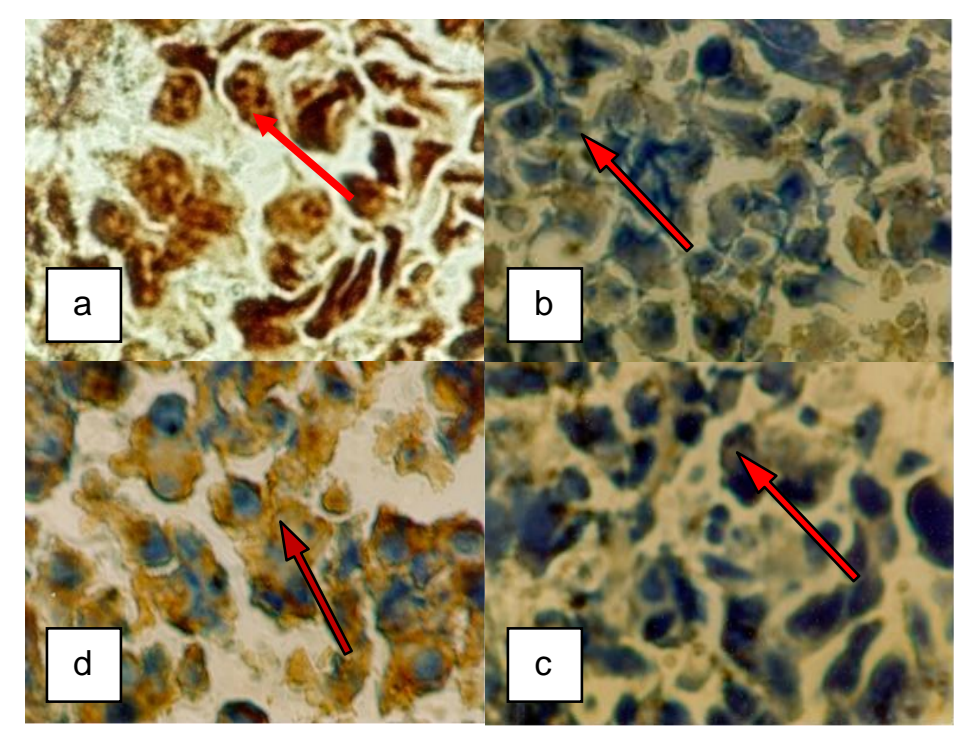

Gambar 3 (a-d). Searah jarum jam, sel yang mengekspresikan AgNORs, p53, Bcl-2, dan Cas-3 (anak panah) pada sel kanker payudara mencit (Mus musculus) galur C3H (perbesaran 1.000x)

Isoflavon yang diberikan mengandung genistein dengan aktivitas antiproliferatif (3-6). Analisis teori ini diperkuat dengan hasil uji LSD (Tabel 1) bahwa bercak AgNORs berturutturut menunjukkan perbedaan secara bermakna antara kelompok $\mathrm{K}$ dengan $\mathrm{P}_{1}$ dan $\mathrm{P}_{2}$ serta antara $P_{1}$ dengan $P_{2} \quad(p=0,000)$. Jumlah sel yang mengekspresikan p53 mengalami penurunan seiring dengan bertambahnya jumlah isoflavon sampai konsentrasi $10.000 \mathrm{mg} / \mathrm{kg}$ diit/hari. Hasil uji LSD menunjukkan bahwa jumlah sel yang mengekspresikan p53 pada tiap kelompok perlakuan berbeda secara bermakna $(p=0,000)$.

\section{BAHASAN}

Kerusakan sel dapat disebabkan oleh kerusakan DNA yang dapat dideteksi pada fase G1 (5,7). Pada saat trigger kerusakan muncul, protein p53 akan berikatan dengan regio promotor gen pada daerah p53 binding domain sebagai ekspresi gen untuk perintah berhenti pada fase G1 guna memperbaiki DNA. Pada sel kanker, peran p53 dalam melawan kerusakan sel pada hewan coba mengarah pada perintah apoptosis. Penanda kanker p53, pada pemberian isoflavon antara kelompok $\mathrm{K}, \mathrm{P}_{1}$, dan $\mathrm{P}_{2}$ menunjukkan rerata berturut-turut 40,$1 ; 13,4$; dan 4,5 sel yang berbeda secara bermakna $(p=0,000)$. Seiring dengan meningkatnya pemberian isoflavon sampai $10.000 \mathrm{mg} / \mathrm{kg}$ diit/hari, terjadi penurunan ekspresi p53. Hal ini berkaitan dengan meningkatnya regulasi p21 dan aberasi yang terjadi pada p53. $\mathrm{Hal}$ ini dapat berlangsung karena senyawa bioaktif isoflavon yang terus ada sebelum dan setelah transplantasi sel kanker pada hewan coba.

Berdasarkan hasil analisis, perubahan D-Bcl-2 menunjukkan sangat bermakna $(p=0,000)$ diikuti perubahan pada D-AgNORs, D-Cas-3, dan D-p53. Variabel D-Bcl-2 mempunyai peran yang lebih besar dibandingkan penurunan variabel pada p53 dan bercak AgNORs. Isoflavon tempe mempunyai aktivitas menghambat enzim tirosin protein kinase yang mengakibatkan menurunnya aktivitas fosforilasi yang diikuti dengan penghambatan sintesis enzim topoisomerase yang berpengaruh pada penghambatan aktivitas replikasi DNA $(14,22)$. Pemberian isoflavon $1.000 \mathrm{mg} / \mathrm{kg}$ diit/hari pada hewan coba, proses apoptosis dan penghambatan proliferasi sel kanker telah dapat dilakukan oleh hewan coba. Aktivitas apoptosis dipengaruhi oleh interaksi antara c-myc, p53, dan Bcl-2 (7). Sel yang mengekspresikan $\mathrm{Bcl}-2$ berturut-turut memberikan perbedaan bermakna antara kelompok kontrol dengan $P_{1}$ dan $P_{2}$, demikian pula antara $P_{1}$ dengan $P_{2} \quad(p=0,000)$. Hasil ini 
menunjukkan bahwa aktivitas apoptosis pada sel kanker hewan coba diperantarai oleh gen Bcl-2. Nilai tertinggi terjadi pada kelompok $P_{2}(10.000 \mathrm{mg} / \mathrm{kg}$ diit/hari) dibandingkan kelompok kontrol dan $P_{1}(1.000 \mathrm{mg} / \mathrm{kg}$ diit/hari). Perubahan jumlah sel yang mengekspresikan Bcl-2 pada tiap kelompok perlakuan menunjukkan rerata berturut-turut dari $\mathrm{K}, \mathrm{P}_{1}$, dan $\mathrm{P}_{2}$ sebesar 17,6 ; 38,7; dan $65,0 / 100$ sel.

Penghambatan proliferasi yang ditunjukkan oleh bercak AgNORs dan data pendukung hasil pengukuran morfometrik pada regresi ukuran jaringan tumor, maka dapat diketahui bahwa Bcl-2 yang diamati adalah Bcl-2 tipe proapoptosis. Terlihat bahwa peran $\mathrm{Bcl}-2$ proapoptosis meningkat. Bcl-2 mempunyai kelompok gen apoptosis antara lain gen Bax. Pada sel kanker, trigger kerusakan yang muncul menyebabkan gen Bcl-2 membentuk heterodimer dengan gen Bax yang merupakan keluarga proapoptosis sehingga terjadi heterodimer Bcl-2-Bax (14,15). Fenomena apoptosis atau sel mati yang diperantarai oleh induksi Bcl-2 ditentukan dengan adanya ekspresi Cas-3. Jumlah sel yang mengekspresikan Cas-3 pada kelompok yang mendapat isoflavon tempe $1.000 \mathrm{mg} / \mathrm{kg}$ diit /hari $\left(\mathrm{P}_{1}\right)$ lebih kecil dibandingkan yang mendapat $10.000 \mathrm{mg} / \mathrm{kg}$ diit/hari $\left(\mathrm{P}_{2}\right)$. Cas-3 sebagai proenzim yang bersifat inaktif dan peran Cas-3 dalam apoptosis adalah sebagai caspase efektor, sebagai akibat sinyal apoptosis. Inisiasi apoptosis dimulai dari pembentukan kompleks Apaf-1-Bcl-2, yang terlepas masuk dalam sitosol yang akan memicu pengaktifan Cas-3 sebagai caspase efektor, dilanjutkan pembentukan heterodimer Bcl-2-Bax yang mengarah pada perintah apoptosis seperti tampak pada Gambar 1.

Hasil analisis diskriminan terhadap respon penghambatan sel kanker payudara mencit (Mus musculus) strain $\mathrm{C} 3 \mathrm{H}$, menunjukkan bahwa semua variabel yaitu AgNORs, p53, Cas-3, dan Bcl-2 mengalami perubahan yaitu secara berturut-turut angka rerata perubahan jumlah sel antara kelompok K- $\mathrm{P}_{1}$ sebesar $-322,0 ;-26,6 ;-16,8$; dan 21,1 sedangkan angka rerata perubahan jumlah sel antara kelompok K- $\mathrm{P}_{2}$ sebesar $-420,7 ;-35,5 ;-24,7$; dan 47,3. $\mathrm{Hal}$ ini menunjukan adanya peran masing-masing gen dalam upaya mempertahan sel pada kondisi normal.

Mekanisme keseimbangan gen kanker payudara akibat pemberian isoflavon nampak pada peran antiproliferatif yang digambarkan pada menurunnya jumlah bercak AgNORs dan peran gen proapoptosis yang digambarkan pada meningkatnya jumlah sel yang mengekspresikan gen Bcl-2. Berturut-turut peran tertinggi terdapat pada sel yang mengekspresikan Bcl-2, AgNORs, dan p53. Penelitian tentang efek pemberian isoflavon terhadap proliferasi dan apoptosis sel kanker payudara pada mencit (Mus musculus) galur $\mathrm{C} 3 \mathrm{H}$ yang telah dilakukan sesuai dengan kriteria inferensi kausal, meliputi kekuatan, konsistensi, kekhususan, temporalitas, gradien biologik, plausibilitas, koherensi, dan bukti eksperimental.

\section{SIMPULAN DAN SARAN}

Isoflavon tempe 1.000 dan $10.000 \mathrm{mg} / \mathrm{kg}$ diit/hari dapat digunakan sebagai agensia untuk mengetahui perubahan biologik parameter AgNORs, p53, Bcl-2, dan Cas-3 menuju perbaikan siklus sel normal. Kontribusi peningkatan Bcl-2 dan terekspresinya Cas-3 pada sel kanker payudara memegang peran dominan pada proses apoptosis sel kanker sedangkan penurunan AgNORs berperan pada penghambatan proliferasi kanker akibat pemberian isoflavon tempe. Urutan penanda gen kanker payudara penentu proses penghambatan proliferasi adalah Bcl-2, Cas-3, p53, dan bercak AgNORs. Gen Bcl-2 dan Cas-3 merupakan variabel diskriminator dalam meningkatkan apoptosis sel kanker hewan coba akibat pemberian isoflavon tempe sebelum dan sesudah transplantasi sel kanker. 
Perlu dilakukan penelitian sejenis, yaitu untuk mengetahui respon penanda kanker payudara yang lain agar diketahui secara pasti peranan isoflavon tempe untuk mencegah proliferasi dan apoptosis sel kanker payudara. Selain itu, perlu juga penelitian sejenis untuk mengetahui kemungkinan tempe segar sebagai suplemen potensial untuk khemoprevensikhemoterapi kanker payudara.

\section{RUJUKAN}

1. Marchbanks PA, McDonald JA, Wilson HG, Folger SG, Mandel MG, Daling JR, Bernstein L, Malone KE, Ursin G, Strom BL, Norman SA, Wingo PA, Burkman RT, Berlin JA, Simon MS, Spirtas R, Weiss LK. Oral contraceptives and the risk of breast cancer. N Engl J Med 2002;346(26):2025-32.

2. McPherson K, Steel CM, Dixon JM. ABC of breast diseases. Breast cancerepidemiology, risk faktor, and genetics. BMJ 2000;321(7261):624-8.

3. Birt DF, Shull JD, Yaktine AL. Chemoprevention of cancer. Within modern nutrition in health and disease. Ninth ed. New York: Lippincott Williams \& Wilkins; 2005.

4. Bruneton J. Essential Oils. Pharmacology: phytochemistry medicinal plants. 2nd ed. Paris: Intercept Ltd; 1999.

5. Toews VD. All about soy isoflavones \& women's health. Garden City Park: Avery Publishing Group; 1999.

6. Onozawa M, Kawamori T, Baba M, Fukuda K, Toda T, Sato H, Ohtani M, Akaza H, Sugimora $\mathrm{T}$, Wakabayashi $\mathrm{K}$. Effect of a soybean isoflavone mixture on carcinogenesis in prostate and seminal vesicles of F344 rats. Jpn J Cancer Res 1999;90(4):393-8.

7. Folmer F. Apoptosis - a review. [series online] 2000 [cited 2003 April 3]. Available from: URL: http://www.geocities.com/Collegepark/Lab/1580/Apoptosis.html

8. Kaplan R, Fisher DE. Apoptosis and cancertherapy. [series online] 2000 [cited 2004 March 23]. Available from: URL: http//www.eurekah. com/ reports/cellcycle/ha

9. Prall OW, Rogan EM, Musgrove EA, Watts CK, Sutherland RL. c-Myc or cyclin D1 mimics estrogen effects on cyclin E-Cdk2 activation and cell cycle reentry. Mol Cell Biol 1998;18(8):4499-508.

10. Vile RG, McClure MO, Weber JN. Genes and cancer. Basic molecular and cell biology. 2nd ed. Tavistock Square, London: BMJ Publishing Group; 1993.

11. Musgrove EA, Swarbrick A, Lee SCL, Cornish AL, Sutherland RL. Mechanisms of cyclin-dependent kinase inactivation by progestins. Mol Cell Biol 1998;18(4):1812825.

12. Neuman E, Ladha MH, Lin N, Upton TM, Miller SJ, DiRenzo J, Pestell RG, Hinds PW, Dowdy SF, Brown M, Ewen ME. Cyclin D1 stimulation of estrogen receptor transcriptional activity independent of cdk4. Mol Cell Biol 1997;17(9):5338-47.

13. Hillman GG, Wang Y, Kucuk O, Che M, Doerge DR, Yudelev M, Joiner MC, Marples B, Forman JD, Sarkar FH. Genistein potentiates inhibitors of tumor growth by radiation in a prostate cancer orthotopic model. Mol Cancer Ther 2004;3(10):1271-9.

14. Worsley SD, Jennings BA, Khalil KH, Mole M, Girling AC. Cyclin D1 amplification and expression in human breast carcinoma: correlation with histological prognostic markers and oestrogen receptor expression. Clin Mol Pathol 1996;49(1):M46-M50.

15. Surh Y-J. Cancer chemoprevention by dietary phytochemicals; a mechanistic viewpoint. Cancer J 1998;11(1):6-10.

16. Clark DP, Russel LD. Moleculer biology. USA: Cache River Press; 1997. 
17. Surh Y-J, Na H-K. Cyclooxygenase-2 as a putative target for cancer chemoprevention some anti inflammatory phytochemicals. Food Chem Toxicol 2002;40:146-51.

18. Bintari SH. Efek isoflavon tempe pada proliferasi kanker mama mencit (Mus musculus) galur $\mathrm{C} 3 \mathrm{H}$ (studi pendahuluan). National Seminar on Medical Biotechnology and its Related Fields: Link Beetween Pharmacetical and Research Universities: Myth or Reality by Medical Biotechnology Laboratory Medical Faculty Diponegoro University in Collaboration with Indonesia; 2007 Jan 27; Semarang.

19. Astawan dan Maskar. Nilai gizi kedelai serta manfaat kesehatan konsumsi kedelai dan produk olahannya. Makalah Pelatihan dan Pengembangan Kuliner Berbasis Tempe; 2011 Okt 9; Pekalongan.

20. Surh Y-J. Anti-tumor promoting potential of selected spice ingredients with antioxidative and anti-inflammatory activities: a short review. Food Chem Toxicol 2002;40(8):1091-7.

21. Griffiths AJF, Miller JH, Suzuki DT, Lewontin RC, Gelbart WM. An introduction to genetic analysis. Sixth ed. New York: W.H Freeman and Company; 1996.

22. Berdanier CD. Advanced nutrition micronutrients. New York: CRC Press; 1998.

23. Toyomura K, Kono S. Soybean, soy foods, isoflavones and risk of colorectal cancer: a review of experimental and epidemiological data. Asian Pac $\mathrm{J}$ Cancer Prev 2002;3(2):125-132.

24. Barnes S. Role of phytochemicals in prevention and treatment of prostat cancer. Epidemiol Rev 2001;23(1):102-5.

25. Jha HC, Kiriakidis S, Hoppe M, Egge H. Antioxidative constituents of tempe. Reinventing the hidden miracle of tempe. Proceedings International Tempe Symposium; 1997 July 13 -15; Bali, Indonesia. Jakarta, Indonesia: Indonesian Tempe Foundation; 1997.

26. Surh Y-J. Molecular mechanisms of chemopreventive effects of selected dietary and medicinal phenolic substances. Mutat Res 1999;428(1-2):305-27.

27. Milner JA, McDonald SS, Anderson DE, Greenwald F. Moleculer targets for nutrients involved with cancer prevention. Nutr Cancer 2001;41(1-2):1-16.

28. Djuanda DG. Penelitian penularan virus tumor mamma (Mtv) pada mencit $\mathrm{C} 3 \mathrm{H}$. Bulletin Penelitian Kesehatan 1974;2(1):26-32. 